\title{
MEKANISME PEMBERHENTIAN KEPALA DAERAH DAN/ATAU WAKIL KEPALA DAERAH MENURUT UNDANG-UNDANG TENTANG PEMERINTAHAN DAERAH TAHUN 1974-2014
}

\author{
Muhammad Syahwalan \\ Mahasiswa Pasca Sarjana Program Studi Hukum Tata Negara IAIN Bengkulu \\ Jalan Raden Fatah Pagar Dewa Bengkulu \\ Email: syahwalan@iainbengkulu.ac.id
}

\begin{abstract}
The problems of Regional autonomy with a centralistic tendency is incarnated in the mechanism of dismissal of regional heads according to Act No. 32 of 2004. A new regional government law has emerged, namely Act No. 9 of 2015 concerning the Second amendment of Act No. 23 of 2014 about Regional Government. This research is a type of normative juridical research with primary sources of regional government laws. The results of the study show that the dismissal of regional heads and/or deputy regional heads is carried out by the DPRD leadership to the President. This proposal is obtained from a series of supervisory processes. If the DPRD leadership is not able to carry out this task, the proposal will be made by the Minister of Home Affairs. The political nuance of each law issued above has an influence on the flexibility of legal ideals to create autonomous regions. The freedom of the region to take care of its own region independently slowly reaches its way until the Act No. 23 of 2014 has been fairly proper in representing the ideals of the region to become more independent and carry out the broadest autonomy in accordance with the constitutional mandate.
\end{abstract}

Keywords: Impeachment Mechanism, Regional Head, Regional Government.

Abstrak: Tarik menarik kebebasan berotonomi dengan kecenderungan sentralistik terjelma pada mekanisme pemberhentian kepala daerah menurut Undang-Undang No. 32 tahun 2004. Ditambah saat ini telah muncul undangundang pemerintahan daerah yang baru yaitu Undang-Undang Nomor 9 Tahun 2015 tentang Perubahan Kedua Atas Undang-Udang Nomor 23 Tahun 2014 Tentang Pemerintahan Daerah. Penelitian ini merupakan jenis penelitian Yuridis Normatif dengan sumber primer Undang-Undang Pemerintah Daerah. Hasil penelitian menunjukan pengusualan pemberhentian kepala daerah dan/atau wakil kepala daerah dilakukan oleh pimpinan DPRD kepada Presiden. Usulan ini didapat dari serangkaian proses pengawasan. Dalam hal pimpinan DPRD tidak dapat melakukan tugas tersebut, maka usul dapat dilakukan oleh menteri dalam negeri. Nuansa politik di setiap masa terbit undang-undang tersebut di atas membuat pengaruh terhadap fleksibilitas cita hukum untuk membuat daerah otonom yang mandiri. Bisa dikatakan bahwa ketidakbebasan daerah mengurus daerah sendiri secara mandiri perlahan tebebas dari belenggu tersebut hingga akhirnya di Undang-undang nomor 23 tahun 2014 ini sudah terbilang cukup baik dalam merepresentasikan cita-cita daerah menjadi lebih mandiri dan menjalankan otonomi yang seluas-luasnya sesuai dengan amanat konstitusi.

Kata Kunci: Mekanisme Pemberhentian, Kepala Daerah, Pemerintahan Daerah 
AL-IMARAH: Jurnal Pemerintahan dan Politik Islam Vol. 3, No. 1, 2018

\section{Pendahuluan}

Ketika sebuah negara berdiri dengan memenuhi unsur terbentuknya sebuah negara, maka tentu muncul persoalan baru yang mungkin tidak terjadi sebelumnya. Begitu juga halnya dengan fenomena persoalan kepala daerah yang sudah termaktub nyata diakui secara yuridis sejak tahun 1974 melalui Undang-Undang Nomor 5 Tahun 1974 tentang Pemerintahan Daerah.

Sebuah cita-cita nyata bangsa untuk menciptakan daerah-daerah otonom yang bisa mengurus rumah tangga daerah sendiri menjadi semakin terkatalisasi dengan perkembangan zaman yang semakin pesat. Undang-undang yang muncul pasca order baru tersebur berumur kurang lebih 25 tahun sebelum akhirnya runtuh bersamaan dengan munculnya era reformasi dan pembentukan undang-undang pengganti yaitu UndangUndang Nomor 22 Tahun 1999. Tepat satu tahun setelah runtuhnya penguasa orde baru yang dituntut secara masif oleh rakyat melalui suara lantang para mahasiswa kala itu.

Fakta di lapangan mengatakan bahwa lahirnya undang-undang nomor 5 Tahun 1974 tersebut justru tidak menjadi sebuah represntasi yang mewakili cita bangsa untuk membuat daerah mandiri, namun dibuat serba tergantung dengan kemauan pemerintah pusat. Aturan-aturan otonomi dalam konstitusi, Undang-Undang Dasar tahun 1945, dan Undang-Undang Pemerintahan Daerah bergerak dalam kerangka tarik-menarik antara kebebasan berotonomi dengan kecenderungan sentralistik. ${ }^{1} \quad$ Tarik menarik tersebut juga terjelma pada mekanisme pemberhentian kepala daerah menurut Undang-Undang No. 32 tahun 2004. Ditambah saat ini telah muncul undang-undang pemerintahan daerah yang baru yaitu Undang-Undangn Nomor 23 Tahun 2014 sebagaimana telah diubah menjadi Undang-Undang Nomor 9 Tahun 2015 tentang Pemerintahan Daerah. Oleh karena itulah tulisan ini ingin membedah secara lebih komprehensif mengenai mekanisme pemberhentian kepala daerah dan/atau wakil kepala daerah berdasarkan undang-undang Pemerintahan daerah yang telah menagalami sebanyak lima (5) kali perubahan.

\section{A. Kajian Teori tantang Demokrasi, dan}

\section{Pertanggungjawaban Jabatan.}

\section{Teori Demokrasi}

Demokrasi merupakan kosakata yang sangat penting dalam khasanah ketatanegaraan. Hal ini didasarkan pada pandangan secar umum bahwa demokrasi ialah nama yang paling baik bagi sistem politik dan sosial suatu negara. ${ }^{2}$ Hasil penelitian yang dilakukan UNESCO pada tahun 1949 mengungkapkan: ${ }^{3}$

1 Setiawan, Dian Bakti. 2011. Pemberhentian Kepala Daerah: Mekanisme Pemberhentiannya Menurut Sistem Pemerintahan di Indonesia. Jakarta: RajaGrafindo Persada. h. 11

${ }^{2}$ Setiawan, Dian Bakti... h 35.

3 Budiarjo, Miriam. 2003. Dasar-Dasar Ilmu Politik. (Jakarta: PT. Gramedia Pustaka Utama). h. 50 
Probably for the first time in history, democracy is claimed as the proper ideal description of system of political and social organization advocated by influential proponent."

Artinya barangkali untuk pertama kalinya dalam sejarah, demokrasi dinamakan sebagai nama yang paling tepat bagi semua sistem organisasi politik dan kemasyarakatan yang dibela oleh pendukung-pendukung yang berpengaruh. Namun disisi lain diskursus demokrasi ini masih dalam bayangan ambiguitas. Robert K. Carr menyatakan bahwa $^{4}$, democracy is not an easy word to define (demokrasi bukanlah sebuah kata yang gampang untuk didefinisikan). Di sisi lain seorang penulis bernama Francois Venter, menyatakan ${ }^{5}$ everyone knows what democracy is, but nobody can define it to general satisfication (semua orang mengetahui apa itu demokrasi, namun tidak ada bisa memberikan definisi yang memuaskan secara umum.

2. Pengertiaan pertanggungjawaban.

Secara etimologi pertanggung jawaban berasal dari kata "Tanggung Jawab" yang menurut Kamus Besar Bahasa Indonesia (KBBI) dapat diartikan bahwa tanggung jawab sebagai

4 Earr, Robert K, et.al. 1960. American Democarcy in Theory and Practice. ( New York:Hart, Reinhart and Weinstern). h. 25-26.

5 Venter, Francois. 2000. Constitutional Comparison, Japan, Germany, Canada and South Africa as constitutional states. (USA: Intam and Co. Ltd, Kuwer Low International 675 Masachuset Avenue, Cambridge). h. 193 keadaan wajib menanggung segala sesuatunya. 6

Ada beberapa derivasi dari kata tanggung jawab seperti: tanggung jawab, mempertanggung jawabkan, penanggung jawab, dan pertanggung jawaban. Bertanggung jawab dalam fungsinya sebagai kata kerja berarti kesediaan untuk memikul tanggung jawab. Sebagai kata sifat berarti kesediaan untuk memikul tanggung jawab. Mempertanggung jawabkan adalah kata kerja yang bermakna memberikan jawaban dan memikul atau menanggung segala akibat yang timbul dalam masalah yang dijawab tersebut.

\section{B. Pemberhentian Kepala Daerah Menurut Undang-Undang Nomor 5 Tahun 1974}

Ketika sistem pemerintahan order baru menguasai negara ini, terdapat sebuah produk hukum yang dihasilkan yaitu lahirnya UndangUndang Nomor 5 Tahun 1974 tentang Pokok Pemerintahan di Daerah. Sebagai sebuah produk hukum yang lahir paska berhentinya rezim orde lama yang dianggap terlalu otokrasi. Cita-cita untuk membangun dan menyeleraskan pemerintahan daerah dalam rangka hubungan antara pusat dan daerah yang lebih demokratis. Gagasan tersebut tertuang di dalam TAP MPRS No XXI/MPRS/1966 tentang pemberian otonomi seluas-luasnya

${ }^{6}$ KBBI daring: Kbbi.kemdikbud.go.id. diakses 27 September 2018 pukul 22.06 wib. 
AL-IMARAH: Jurnal Pemerintahan dan Politik Islam

Vol. 3, No. 1, 2018

kepada daerah memuat pokok-pokok sebagai berikut ${ }^{7}$ :

1. Menugaskan pemerintah dan Dewan Perwakilan Rakyat-Gotong Royong (DPR-GR) dalam waktu sesingkatsingkatnya memberikan otonomi seluas-luasnya kepada daerah sesuai dengan jiwa da nisi Undang-Undang Dasar (UUD) 1945 dengan tidak mengurangi tanggung jawab pemerintah di bidang koordinasi, perencanaan, dan pengawasan terhadap daerah(pasal 1).

2. Menyerahkan urusan, disertai dengan penyerahan aparatur dan kewenangannya, kecuali yang bersifat nasional, yang akan ditentukan dan diatur dengan undang-undang (pasal 2).

3. Daerah diberi kewenangan dan tanggung jawab mengatur kepegawaian dalam lingkungan pemerintahan daerah (pasal 3).

4. Pengaturan kembali tentang perimbangan keuangan.

5. Peninjauan kembali tentang UU No. 18 Tahun 1965,UU No. 19 Tahun 1965, dan paragraf 392 No.1 Angka 4 Tap No.II/MPRS/1960 (pasal 5).

6. Tentang kedudukan khusus Irian Barat (pasal 6).

\footnotetext{
${ }^{7}$ Setiawan, Dian Bakti. .... h.89
}

7. Tugas-tugas tersebut harus selesai dalam waku tiga taahun terhitung sejak dikeluarkannya Ketetapan MPRS No. XXI/MPRS/1966.

Pemberhentian kepala daerah diatur dalam pasal 21 yang menyatakan bahwa kepala daerah berhenti atau diberhentikan oleh pejabat yang berhak mengangkat karena:

a. Meninggal dunia;

b. Atas permintaan sendiri;

c. Berakhir masa jabatannya dan telah dilantik Kepala Daerah baru;

d. Melanggar sumpah/janji yang dimaksud dalam pasal 18ayat (4) Undang-Undang ini;

e. Tidak lagi memenuhi sesuatu syarat yang dimaksud dalam pasal 14 Undang-Undang ini;

f. Melanggar ketentuan yang dimaksud dalam pasal 20 UndangUndang ini;

g. Sebab-sebab lain.

Selanjutnya perlu pula kita memperhatikan ketentuan pada pasal 22 ayat (2) yang berbunyi: "dalam hal menjalankan hak dan wewenang dana kewajiban pemerintahan daerah, Kepala Daerah secara hierarki bertanggung jawab kepada presiden melalui Menteri Dalam Negeri.'

Hal ini kemudian diperjelas kembali dalam ayat (3) yang menyatakan bahwa, "dalam menjalankan hak wewenang dan kewajiban 
pemerintahan daerah, Kepala Daerah berkewajiban memberikan keterangan pertanggungjawaban kepada Dewan Perwakilan Rakyat Daerah sekurangkurangnya sekali dalam setahun, atau jika dipandang perlu olehnya, atau apabila diminta oleh Dewan Perwakilan Rakyat Daerah."

Pemberhentian kepala daerah berdasarkan undang-undang ini akan dianalis dengan teori demokrasi, toeri pertanggung jawaban dan tata cara pemberhentian Kepala Daerah sebagai dasar analisis dan beberapa pokok pikiran dalam UU No. 5 Tahun 1974 seperti yang diuraikan di atas sebagai bahan analisis.

Menurut Mahfud MD $^{8}$, ketika berlangsung transisi pemerintahan dari orde lama ke orde baru, orde baru menggunakan sistem politik yang demokratis dengan penekana pada kehidupan politik yang konstitusional. Dalam masa itulah dihasilkan Tap MPRS No. XXI/MPRS/1966 yang menggunakan prinsip otonomi yang nyata dan seluas-luasnya. Namun penekanan pada konfigurasi politik yang demokratis ini justru hanya berlangsung sementara, sebagai strategi awal pemerintah sebelum berhasil membuat corak politik baru. Ketika format politik baru berhasil disusun, sebagaimana tertuang dalam UU No. 15 Tahun 1969 tentang Pemilu dan

\footnotetext{
${ }^{8}$ Mahfud MD, 1999. Pergulatan Politik dan Hukum di Indonesia. (Yogyakarta: Gama Media). h.195
}

UU No. 16 Tahun 1969 tentang Susunan dan Kedudukan MPR, DPR, dan DPRD, konfigurasi politik Indonesia kembali menjadi otoriter sehingga produk hukum tentang hubungan pusat dan daerah diletakkan dalam bingkai yang terpusat (sentralistik) dan dekonsentratif. Dari kaca mata demokrasi, tatanan politik yang dibangun oleh Orde Baru memang tidak menguntungkan, orde baru menurut Gerhet Feith, merupakan

"suatu fraksi dari persekutuan yang kompleks antarkelas teknokrat perkotaan, administratif perkantoran, kelas pengelola kota (yang dinamakan kelas menengah), dan kaum birokrat politik dan militer,"9

Pembangunan politik di era Orde Baru berorientasi pada pertumbuhan ekonomi. Hal ini berjalan dengan baik jika didukung oleh stabilitas politik yang baik. Dalam hal mencapai stabilitas tersebut maka tebagi dalam dua dimensi yakni dimensi struktural dan dimensi kultural. ${ }^{10}$ Dimensi kultural ditujukan pada suprastruktur dan infrastruktur politik. Dalam kerangka inilah dikeluarkan undangundang tentang pemilu dan parpol. Dimensi kultural ditandai dengan pemasyarakatan ideologi pancasila. Diletakkannya stabilitas nasional dalam arti stabilitas politik pada tempat utama, membawa dampak pada pelaksanaan otonomi daerah. Daerah harus

${ }^{9}$ Dikutip dari J.Kaloh.2002. Mencari Bentuk Otonomi Daerah. (Jakarta: Rineka Cipta). h. 19

${ }^{10}$ Setiawan, Dian Bakti...... h. 117 
ditempatkan dalam kendali pusat, sebab perundang-undangan tersebut. ${ }^{11}$ Ketentuan ketidakstabilan keadaan di daerah akan lebih lanjut (peraturan pelaksana) ini biasanya menjadi sebuah ancaman bagi stabilitas politik dibuat atas dasar atribusi/delegasi yang sangat secara meneyeluruh di wilayah Indonesia. loggar sehingga memberi peluang yang besar Oleh sebab itulah Garis-Garis Besar Haluan bagi adanya campur tangan pemerintah yang Negara (GBHN) menggariskan otonomi membawa pemerintah pada kedudukan yang daerah sebagai otonomi yang nyata dan sangat menentukan. bertanggung jawab. Seperti halnya yang dijelaskan oleh Undang-undang no.5 tahun 1974, bahwa bertanggung jawab mencakup hal-hal terkait:

a. Sesuai dengan pembinaan politik dan kesatuan bangsa.

b. Harus dapat menjamin hubungan yang serasi antara pemerintah pusat dan daerah atas dasar keutuhan negara kesatuan.

c. Harus dapat menjamin pertumbuhan dan pembangunan daerah.

Undang-undang No. 5 Tahun 1974 ini penuh dengan makna pemusatan kekuasaan (sentralistik). Hal ini bisa dilihat secara nyata dari banyaknya atribusi dan delegasi kewenang yang diberikan oleh UndangUndang kepada pemerintah untuk membuat aturan yang lebih lanjut mengenai beberbagai ketentuan. Hal tersebut banyak tertuang di dalam Peraturan Pemerintah, Keputusan Presiden, Instruksi Menteri, Keputusan Menteri, Peraturan Menteri dan sebagainya. Mahfud MD mencatat terdapat kurang lebih 34 ketentuan yang diatur lebih lanjut oleh pemerintah dengan berbagai bentuk

Dari segi substansi, pokok-pokok pikiran dalam UU No. 5 Tahun 1974, sebagaimana dibahas di atas telah menggiring pemerintah dearah jauh ke arah sentralisasi daripada desentralisasi. Asas dekonsentrasi yang digunakan sejajar dengan desentraliasi tidak lepas dari kecenderungan pola hubungan pusat dan daerah yang sentralistik yang dikembangan melalui uu ini. Kajian-kajian ilmiah menunjukkan bahwa ketentuan dekonsentrasi ini secara konstitusional tidak dapat didasarkan pada pasal 18 UUD 1945 (sebelum amandemen). Sesuatu yang secara eksplisit dinyatakan sebagai sandaran utama UU No. 5 Tahun 1974. Akibat elemen dekonsentrasi, di daerah dibentuk "wilayah" sebagai pelaksana tugas-tugas pemerintahan umum. Kepala wilayah, untuk menghilangkan dualisme pemerintahan di daerah, dirangkap oleh kepala daerah.

Ditinjau dari segi kedudukan kepala daerah, dualisme ini ternyata memberi konsekuensi munculnya kecenderungan bahwa kedudukan tersebut labih sebagai kepala wilayah daripada kepala daerah, sebab h. $199-203$ 
kedudukan kepala daerah yang memimpin pelaksanaan otonomi daerah ternyata diberi ruang lingkup urusan yang sempit. Menurut Bagir Manan ${ }^{12}$ bila ditinjau sistem rumah tangga yang dikehendaki oleh UU No. 5 Tahun 1974, terdapat inkonsistensi antara penjelesan yang menyatakan secara eksplisit bahwa otonomi yang dijalankan merupakan otonomi nyata dengan ketentuan-ketentuan dalam pasal-pasal pada batang butuh UU ini merupakan sistem rumah tangga materiil, urusan yang diatur dan diurus oleh daerah sangatlah terbatas. Sebab bila dihubungkan dengan sistem pengawasan akan didapati bahwa pengawasan sangat membatasi keleluasan kekuasaan daerah dalam berotonomi. Dilihat dari segi pengawasan preventif, ada ketentuan dalam penjelasan umum bahwa dalam pengesahan diperlukan dalam hal keputusan kepala daerah memuat ketentuan yang ditujukan secara langsung kepada rakyat, ketentuan pidana, ketentuan yang membebani rakyat dan ketentuan yang perlu diketahui umum. Semua hak yang bersifat pencegahan sangat membatasi kebebasan berotonomi. Implikasi nyata dari pembatasan kebebasan otonomi tersebut ialah munculah tugas-tugas dekonsentrasi, yang artinya porsi kedudukan yang lebih dominan ialah porsi kedudukan sebagai kepada wilayah.

12 Manan, Bagir. 1990. Hubungan Antara Pusat dan Daerah Berdasarkan Desentralisasi Menurut UUD 1945. Disertasi. h. 315
Sebagai kepala wilayah tentunya garis pertanggungjawaban yang diberikan tentu pada pemerintah pusat. Hal ini telah dijelaskan secara gamblang di dalam UU tersebut bahwa pemerintah daerah adalah kepala daerah dan DPRD. Konstruksi ini justru meletakkan posisi DPRD sebagai bagian dari elemen pemerintah daerah. Di sisi lain dikemukakan pula bahwa kepala wilayah berwenang membimbing dan mengawasi penyelenggaraan pemerintah daerah seperti yang termaktub di dalam Pasal 81 huruf e UU tersebut. Karena kepala wilayah adalah kepala daerah, maka secara otomatis pemerintah daerah yang akan dibimbing langsung hanyalah DPRD saja. Secara eksplisit, UU No.5 Tahun 1974 mengatur persoalan pertanggung jawaban kepala daerah. Hal ini dengan hierarki kepala daerah bertanggung jawab kepada pemerintah pusat dalam hal ini Presiden melalui Menteri Dalam Negeri (Pasal 22 ayat (2)). Sedangkan penyampaian keterangan pertanggung jawaban hanya diiberikan oleh kepala daerah kepada DPRD (Pasal 22 ayat (3)).

Dikarenakan keterbatasan tugas otonomi, pertanggung jawaban yang diberikan kepala daerah dalam kedudukan lebih sebagai aparat pusat dibandingkan sebagai kepala daerah otonom. Hal ini disebabkan karena pengurangan porsi demokrasi dalam penyelenggaraan negara untuk meningkatkan stabilitas politik dalam rangka mengejar tujuan utama yaitu pertumbuhan ekonomi. Oleh 
AL-IMARAH: Jurnal Pemerintahan dan Politik Islam Vol. 3, No. 1, 2018

sebab itulah, kepala daerah hanya dapat diberhentikan oleh pejabat yang mengangkat seperti yang tertuang dalam pasal 21 UU ini. Presiden berhak mengangkat kepala daerah tingkat I dan Menteri Dalam Negeri berhak mengangkat kepala daerah tingkat II seperti yang termaktub di dalam pasal 15, 16, dan 18 .

\section{Pemberhentian Kepala Daerah Menurut Undang-Undang No. 22 Tahun 1999.}

Menurut Undang-Undang Nomor 22 Tahun 1999 tentang Pemerintahan Daerah, terdapat tiga substansi dalam ranah pemberhentian kepala daerah yakni pasal pasal 46, pasal 49, dan pasal 51 dan 52.

1. Pasal 49 berbunyi, "kepala daerah berhenti dan diberhentikan karena :

a. Meninggal dunia;

b. Mengajukan berhenti atas permintaan sendiri;

c. Berakhir masa jabatannya dan telah dilantik pejabat yang baru

d. Tidak lagi memenuhi syarat sebagaimana yang dimaksud dalam pasal 33;

e. Melanggar sumpah/janjii sebagaimana yang dimaksud pasl 42 ayat (3);

f. Melanggar ketentuan sebagaimana yang dimaksud dalam pasal 48 dan;

g. Mengalami krisis kepercayaan publik yang luas akibat kasus yang melibatkan tanggung jawabnya dan keterangannya atas kasus itu ditolak oleh DPRD.

Poin-poin yang berkaitan dengan pemberhentian kepala daerah sesuai pasal di atas terdapat pada huruf c,d,e,f, dan g. Namun sedikit berbeda dari poin lain, poin pada huruf b didasarkan pada permintaan sendiri. Dalam bahasa lain dikenal dengan istilah berhenti melalui proses pengunduran diri.

\section{Pasal 46 UU No 22 tahun 1999}

Menurut Pasal ini kepala daerah yang ditolak pertanggung jawabannya setiap kali diminta oleh DPRD, baik berkenaan dengan kebijakan pemerintah atau keuangan, harus melengkapi dalam jangka waktu tiga puluh (30) hari. Jika terjadi penolakan yang kedua maka DPRD dapat mengusulkan pemberhentian kepala daerah kepada presiden.

Mekanisme pemberhentian tersebut melibatkan DPRD dan Presiden. Pertama DPRD akan menilai pertanggungjawabannya. Jika DPRD melakukan penolakan atas laporan pertanggungjawaban tersebut, maka DPDRD dapat mengusulkan pemberhentian kepala daerah tersebut kepada DPRD. Hal ini prinsipnya diberhentikan atau tidak kepala daerah tersebut masih tergantung kepada presiden. Dapat ditarik kesimpulan sederhana atas komparasi pola pemberhentian pada pasal 49 dan 46. Pasal 49 secara prinsip DPRD 
Muhammad Syahwalan:

Mekanisme Pemberhentian Kepala Daerah Dan/Atau Wakil Kepala Daerah Menurut Undang-Undang Tentang Pemerintahan Daerah Tahun 1974-2014

dapat memberikan keputusan pemberhetian kepala daerah, sedangkan presiden hanya mengesahkan. Namun keduanya memiliki keseragaman yaitu, inisiatif untuk memberhentikan kepala daerah sama-sama berasal dari DPRD.

\section{Pasal 51 dan 52}

Menurut pasal ini, kepala daerah diberhentikan oleh presiden melalui keputusan DPRD apabila terbukti melakukan tindak pidana kejahatan yang diancam dengan hukuman mati sebagaimana diatur dalam kitab undang-undang hukum pidana. Substansi dalam bentuk pidana hanya diatur dalam pasal 52, yaitu dalam bentuk pidana materiil. Mekanisme pemberhentian kepala daerah menurut kedua pasal ini melibatkan presiden dan badan peradilan. Pengadilan akan melakukan proses pemeriksaan dan mengeluarkan putusan yang definitif. Sehingga putusan pengadilan inilah yang menjadi alasan pemberhentian kepala derah oleh presiden.

\section{Mekanisme Pemberhentian Kepala}

Daerah Dalam Masa Jabatannya Menurut Undang-Undang No. 32 Tahun 2004.

Ketentuan-ketentuan mengenai pemberhentian kepala daerah terdapat dalam pasal 29, 30, 31, dan 32. Pasal 29 ayat (2) mengatur alasan pemberhentian kepala daerah, yakni:
1. Berakhir masa jabatannya dan telah dilantik pejabat yang baru;

2. Tidak dapat melaksanakan tugas secara berkelanjutan atau berhalangan tetap secara berturutturut selama 6 (enam) bulan;

3. Tidak lagi memenuhi syarat sebagai kepala daerah;

4. Dinyatakan melanggar sumpah/janji jabatan;

5. Tidak melaksanakan kewajiban kepala daerah;

6. Melanggar larangan bagi kepala daerah.

- Kewenangan Presiden dalam mekanisme pemberhentian kepala daerah.

Kewenangan pemberhentian oleh presiden tersebut didasarkan pada fungsi pengawasan terhadap daerah yang dilakukan oleh pemerintah pusat. Menurut Robert J. Mochler ${ }^{13}$ memberikan pengertian tentang pengawasan yaitu, suatu usaha sistematis untuk menetapkan umpan balik, membandingkan kegiatan nyata dengan standar yang telah ditetapkan sebelumnya, menentukan dan mengukur penyimpanganpenyimpangan, serta mengambil standar pelaksanaan dengan tujuan-tujuan perencanaan, merancang sistem informasi, dan tindakan koreksi yang diperlukan.

13 Djohermansyah Djohan. 2003. Kebijakan Otonomi Daerah 1999.(Jakarta: Yarsif Watampane). h. 155. 
Dalam mekanisme pemberhentian kepala daerah menurut UU No. 32 Tahun 2004, pengawasan presiden berlaku untuk seluruh pemberhentian kepala daerah dalam masa jabatannya. Untuk pemberhentian yang didasarkan pada isi yang diatur pada pasal 29 dan 31, presiden menggunakan kewenangannya dalam rangka pengawasan setelah melalui proses yang bersifat internal di daerah otonom yang bersangkutan, bahkan setelah adanya penilaian terhadap substansi tersbut dari Mahkamah Agung. Untuk pemberhentian yang diatur pada pasal 30 dan 32 kewenangan pengawasan tersebut digunakan tanpa melalui proses internal di daerah yang bersangkutan, tetapi sudah melalui proses peradilan. Substansi yang terkandung dalam pasal 29 didominasi oleh persoalan politik, persoalan hukum, dan arti yang lebih luas persoalan hukum ketatanegaraan. Sedangkan pada pasal 32 terdapat substansi pidana yang terkandung unsur politik pada klausul "krisis kepercayaan publik yang meluas". ${ }^{14}$

Di sisi lain unsur yang terdapat dalam pasal 30 dan 31 justru mengandung unsur pidana murni. ${ }^{15}$ Secara ringkas dapat ditarik kesimpulan bahwa untuk mekanisme pemberhentian kepala daerah menurut Undang-Undang No. 32 Tahun 2004 ialah didasarkan pada substansi politik atau hukum tata negara atau hukum pidana yang

\footnotetext{
${ }^{14}$ Setiawan, Dian Bakti.... h. 199

${ }^{15}$ Setiawan, Dian Bakti.... h. 199
}

mengandung nuansa politik, kewenangan pengawasan presiden dilakukan setelah adanya proses internal di daerah dan penilaian /putusan Mahkamah Agung/Peradilan. Sedangkan pemberhentian karena adanya unsur pidana murni dilakukan setelah adanya proses peradilan. Presiden melakukan pemberhentian terhadap kepala daerah yang bersangkutan sudah sesuai dengan aturan yang berlaku dengan mengedepankan unsur penilaian yang comprehensi baik dari badan peradilan/MA maupun DPRD.

\section{- Kewenangan DPRD dalam} mekanisme pemberhentian kepala daerah.

Salah satu fungsi atau kewenangan DPRD adalah melakukan tugas pengawasan (controlling). Seperti yang dikemukakan oleh Jimly, ${ }^{16}$ secara teoritis, jika dirinci, fungsifungsi pengawasan oleh parlemen/DPRD sebagai lembaga perwakilan rakyat dapat dibedakan menjadi sebagai berikut:

- Pengawasan terhadap penentuan kebijakan (control of policy making)

- Pengawasan terhadap pelaksanaan kebijakan (Control of Policy Executing)

- Pengawasan terhadap penganggaran dan belanaja negara (control of budgeting).

16 Jimly Asshiddiqie.2006. Pengantar Ilmu Hukum Tata Negara Jilid II. (Jakarta: Sekretariat Jenderal dan Kepaniteraan Mahkamah Konstitusi RI). h. 36 
Muhammad Syahwalan:

Mekanisme Pemberhentian Kepala Daerah Dan/Atau Wakil Kepala Daerah Menurut Undang-Undang Tentang

Pemerintahan Daerah Tahun 1974-2014

- Pengawasan terhadap pelaksanaan anggaran dan belanja Negara (control of budget implementation)

- Pengawasan terhadap kinerja pemerintahan (control of government performance)

- Pengawasan terhadap pengangkatan pejabat public (control of political appointment of public officials) dalam bentuk persetujuan atau penolakan, ataupun dalam bentuk pemberian pertimbangan oleh DPR.

Terdapat dua system pemerintahan yang terkenal di dunia yaitu sistem parlementer dan sistem presidensil. Pada sistem parlementer, DPRD dapat melakukan tugasnya mengawasi dan memberhentikan kepala daerah, sebab hal ini didasarkan pada paham pertanggungjawaban eksekutif (kepala daerah) kepada parlemen (DPRD). Sedangkan dalam sistem presidensil, mekanisme ini tidak bisa dilakukan, sebab kepala daerah bertanggung jawab langsung bertanggung jawab kepada voters/pemilih yang dalam hal ini yaitu rakyat demi tercapainya stabilitas politik. Namun melalui lembaga impeachment, yang dilaksankan DPRD, kepala daerah dapat saja diberhentikan jika terbukti melakukan pelanggaran terhadap hukum/aturan yang berlaku. Substansi pemberhentian kepala daerah yang diberlakukan oleh UU No. 32 Tahun 2004 ini merupakan alasan substansi politik, bukan semata-mata karena hukum.

\section{E. Mekanisme Pemberhentian Kepala} Daerah Menurut Undang-Undang No. 23 Tahun 2014 Tentang Pemerintahan

\section{Daerah}

Menurut undang-undang nomor 23 tahun 2014, terdapat tiga substansi pasal yang menerangkan alasan pemerintah daerah dalam hal ini kepala daerah dapat diberhentikan. Ketentuan tersebut terdapat pada pasal 78, 79, dan 80. Pasal 78 ayat (1) berbunyi, "Kepala daerah dan/atau wakil kepala daerah berhenti karena:
a. Meninggal dunia;
b. Permintaan sendiri; atau
c. Diberhentikan.

Pasal 78 ayat (2), kepala daerah dan atau wakil kepala daerah diberhentikan sebagaimana dimaksud pada ayat (1) huruf c karena:

a. Berakhir masa jabatannya;

b. Tidak dapat melaksanakan tugas secara berkelanjutan atau berhalangan tetap secara berturut-turut selama 6 (enam) bulan;

c. Dinyatakan melanggar sumpah/janji jabatan kepala daerah/wakil kepala daerah;

d. Tidak melaksanakan kewajiban kepala daerah dan wakil kepala daerah sebagaimana dimaksud dalam pasal 67 huruf $b$;

e. Melanggar larangan bagi kepala daerah dan wakil kepala daerah sebagaimana 
dimaksud dalam pasal 76 ayat (1), pimpinan DPRD tidak melakukan tindakan kecuali huruf c, huruf $i$, dan huruf $j$; pengusulan pemberhentian terhadap kepala

f. Melakukan perbuatan tercela;

g. Diberi tugas dalam jabatan tertentu daerah dan/atau kepala daerah tersebut, maka oleh presiden yang dilarang untuk dirangkap oleh ketentuan peraturan perundang-undangan;

h. Menggunakan dokumen dan/atau keterangan palsu sebagai persyaratan pada saat pencalonan kepala daerah/wakil kepala daerah berdasarkan pembuktian dari lembaga yang berwenang menerbitkan dokumen; dan/ataul

i. Mendapatkan sanksi pemberhentian.

Kemudian mekanisme pemberhentian kepala daerah dan/atau wakil kepala daerah seperti yang termaktub di dalam pasal 79 ayat (1) yakni, pemberhentian kepala daerah dan/atau wakil kepala daerah sebagaimana dimaksud dalam Pasal 78 ayat (1) huruf a dan huruf b serta ayat (2) huruf a dan huruf $b$ diumumkan oleh pimpinan DPRD dalam rapat paripurna dan diusulkan oleh pimpinan DPRD kepada Presiden melalui Menteri untuk gubernur dan/atau wakil gubernur serta kepada Menteri melalui gubernur sebagai wakil Pemerintah Pusat untuk bupati dan/atau wakil bupati atau wali kota dan/atau wakil wali kota untuk mendapatkan penetapan pemberhentian.

Sebagai wujud preventif, undangundang ini memberikan alternatif lain seperti yang tertuang dalam ayat (2) yakni jika kepada kepala daerah dan/atau kepala daerah melalui usul Menteri. Baik melalui usul atau tidak melalui usul gubernur, ${ }^{17}$ menteri dapat memberhentikan bupati dan/atau wakil bupati atau wali kot dan/atau wakil wali kota sebagi bentuk pelaksanaan fungsi perwakilan pemerintah pusat.

\section{- Ketentuan pemberhentian kepala} daerah dan/atau wakil kepala daerah

Seperti yang tertuang di dalam pasal 78 ayat (2) huruf c, huruf d, dan huruf e, dan/atau huruf f, maka pelaksanaan pemberhentian kepala daerah dan/atau wakil kepala daerah mengikuti ketentuan bahwa usul pemberhetian kepala daerah dan/atau wakil kepala daerah setingkat gubernur dan/atau wakil gubernur ditujukan kepada presiden, dan ditujukan kepada menteri jika bupati dan/atau wakil bupati atau wali kota dan/atau wakil wali kota. Usulan tersebut harus berdasarkan putusan Mahkamah Agung atas pendapat DPRD. Mahkamah Agung harus memeriksa, mengadili, dan memutusan pendapat yang diajukan oleh DPRD paling lambat selama 30 hari setelah permintaan diterima dan putusan tersebut bersifat final.

${ }^{17}$ Pasal 79 ayat (2) dan ayat (3) UU No. 23 tahun 2014. 
Pendapat yang diberikan oleh DPRD ini harus diputuskan dalam rapat paripurna dengan diahdiri anggota $3 / 4$ dari seluruh jumlah anggota DPRD dan putusan diambil paling sedikit 2/3 dari jumlah anggota DPRD yang hadir.

Apabila ternyata dalam fakta di lapangan disebutkan bahwa kepala daerah dan/atau wakil kepala daerah terbukti melanggar larangan yang telah ditetapkan oleh undang-undang ini, maka pimpinan DPRD harus menyampaikan usul secara langsung kepada presiden. Usul yang diterima presiden wajib ditanggapi dan dilakukan pemberhentian terhadap kepala daerah dan/atau wakil kepala daerah dalam hal ini gubernur dan/atau wakil gubernur paling lambat 30 hari sejak usul tersebut diterima.begitu juga halnya yang harus dilakukan menteri terhadap pemberhentian bupati dan/atau wakil bupati atu wali kota dan/atau wakil wali kota.

Namun sikap preventif ditunjukan oleh keberlakuan undang-undang ini. Dalam hal jika pimpinan DPRD tidak menyampaikan usul pemberhentian kepala daerah dan/atau wakil kepala daerah kepada presiden paling lambat 14 hari setelah putusan MA, maka presiden dapat melakukan pemberhentian terhadap kepala daerah dan/atau wakil kepala daerah dalam hal ini gubernur dan/atau wakil gubernur melalui usul menteri. Serta menteri dapat memberhentikan bupati dan/atau wakil bupati atau wali kota dan/atau wakil wali kota melalui usul gubernur.

Terhadap pelanggaran yang dilakukan oleh kepala daerah dan/atau wakil kepala daerah yang diduga menggunakan dokumen dan/atau keterangan palsu sebagai persyaratan pada saat pencalonan kepala daerah dan/atau wakil kepala daerah berdasarkan pembuktian dari lembaga yang berwenang menerbitkan dokumen, DPRD bisa menggunakan hak angket untuk melakukan penyelidikan. Seperti yang diketahui secara umum, hak angket ialah hak DPR/badan legislatif untuk melakukan penyelidikan terhadap pelaksanaan suatu undang-undang/kebijakan pemerintah yang berkaitan dengan hal penting, strategis, dan berdampak luas pada kehidupan bermasyarakat, berbangsa, dan bernegara yang diduga bertentangan dngan perturan perundang-undangan. ${ }^{18}$ Dalam hal pelanggaran yang dilakukan oleh kepala daerah dan/atau wakil kepala daerah tersebut terbukti setelah melalui serangkaian pemeriksaan, maka usul pemberhentian kepala daerah dan/atau wakil kepala daerah disampaikan kepada presiden untuk pemberhentian gubernur dan/atau wakil gubernur melalui menteri, dan melalui gubernur untuk pemberhentian bupati dan/atau wakil bupati diusulkan kepada menteri.

${ }^{18}$ Dpr.go.id/tentang/hak-dpr. Diakses pada hari Selasa, 27 November 2018, pukul 15.04 wib 
AL-IMARAH: Jurnal Pemerintahan dan Politik Islam

Vol. 3, No. 1, 2018

\section{Penutup}

Dari pembahan yang cukup panjang dalam artikel ini mengenai pemberhentian kepala daerah maka dapat ditarik sebuah kesimpulan bahwa pemberhentian kepala daerah dan atau wakil kepala daerah dimulai dari Undang-undang Nomor 5 tahun 1974, Undang-Undang Nomor 22 Tahun 1999, Undang-Undang Nomor 32 Tahun 2004, dan terakhir Undang-Undang Nomor 23 Tahun 2014 tentang pemerintahan daerah hampir memiliki kesearagam, yaitu pengusualan pemberhentian kepala daerah dan/atau wakil kepala daerah dilakukan oleh pimpinan DPRD kepada Presiden. Usulan ini didapat dari serangkaian proses pengawasan. Dalam hal pimpinan DPRD tidak dapat melakukan tugas tersebut, maka usul dapat dilakukan oleh menteri dalam negeri. Nuansa politik di setiap masa terbit undang-undang tersebut di atas membuat pengaruh terhadap fleksibilitas cita hukum untuk membuat daerah otonom yang mandiri. Bisa dikatakan bahwa ketidakbebasan daerah mengurus daerah sendiri secara mandiri perlahan tebebas dari belenggu tersebut hingga akhirnya di Undang-undang nomor 23 tahun 2014 ini sudah terbilang cukup baik dalam merepresentasikan cita-cita daerah menjadi lebih mandiri dan menjalankan otonomi yang seluas-luasnya sesuai dengan amanat konstitusi.

\section{Pustaka Acuan}

Budiarjo, Miriam. 2003. Dasar-Dasar Ilmu Politik. (Jakarta: PT. Gramedia Pustaka Utama).

Dikutip dari J.Kaloh.2002. Mencari Bentuk Otonomi Daerah. (Jakarta: Rineka Cipta).

Djohermansyah Djohan. 2003. Kebijakan

Otonomi Daerah 1999.(Jakarta: Yarsif Watampane).

Dpr.go.id/tentang/hak-dpr. Diakses pada hari Selasa, 27 November 2018, pukul 15.04 wib

Earr, Robert K, et.al. 1960. American Democarcy in Theory and Practice. ( New York:Hart, Reinhart and Weinstern).

Jimly Asshiddiqie.2006. Pengantar Ilmu Hukum Tata Negara Jilid II. (Jakarta: Sekretariat Jenderal dan Kepaniteraan Mahkamah Konstitusi RI).

KBBI daring: Kbbi.kemdikbud.go.id. diakses 27 September 2018 pukul 22.06 wib.

Mahfud MD, 1999. Pergulatan Politik dan Hukum di Indonesia. (Yogyakarta: Gama Media).

Manan, Bagir. 1990. Hubungan Antara Pusat dan Daerah Berdasarkan Desentralisasi Menurut UUD 1945. Disertasi.

Pasal 79 ayat (2) dan ayat (3) UU No. 23 tahun 2014.

Setiawan, Dian Bakti. 2011. Pemberhentian Kepala Daerah: Mekanisme Pemberhentiannya Menurut Sistem 
Pemerintahan di Indonesia. Jakarta:

RajaGrafindo Persada.

Venter, Francois. 2000. Constitutional

Comparison, Japan, Germany, Canada

and South Africa as constitutional states.

(USA: Intam and Co. Ltd, Kuwer Low

International 675 Masachuset Avenue,

Cambridge). 